Article

\title{
Sinularones A-I, New Cyclopentenone and Butenolide Derivatives from a Marine Soft Coral Sinularia sp. and Their Antifouling Activity
}

\section{Haiyan Shi ${ }^{1}$, Shanjiang Yu ${ }^{2}$, Dong Liu ${ }^{1}$, Leen van Ofwegen ${ }^{3}$, Peter Proksch ${ }^{4}$ and Wenhan Lin ${ }^{1, *}$}

1 State Key Laboratory of Natural and Biomimetic Drugs, Peking University, Beijing 100191, China; E-Mails: 775278625@qq.com (H.S.); liudong_1982@126.com (D.L.)

2 China National Center for Biotechnology Development, Beijing 100036, China; E-Mail: yushj@cncbd.org.cn

3 National Museum of Natural History Naturalis, 2300 RA, Leiden 9515, The Netherlands; E-Mail: ofwegen@naturalis.nnm.nl

4 Institute of Pharmaceutical Biology and Biotechnology, Heinrich-Heine University, Duesseldorf 40225, Germany; E-Mail: proksch@uni-duesseldorf.de

* Author to whom correspondence should be addressed; E-Mail: whlin@bjmu.edu.cn; Tel.: +86-10-8280-6188; Fax: +86-10-8280-2724.

Received: 12 March 2012; in revised form: 16 April 2012 / Accepted: 4 June 2012 / Published: 11 June 2012

\begin{abstract}
Nine new compounds, namely sinularones A-I (1-9), characterized as cyclopentenone and butenolide-type analogues, were isolated from a soft coral Sinularia sp., together with a known butenolide (10). Their structures were elucidated by means of spectroscopic (IR, MS, 1D and 2D NMR, CD) analysis. The absolute configurations were determined on the basis of $\mathrm{CD}$ and specific rotation data in association with the computed electronic circular dichroism (ECD) by time dependent density functional theory (TD DFT) at 6-31+G $(d, p) / / \mathrm{DFT}$ B3LYP/6-31+G $(d, p)$ level. Compounds 1-2 and 7-10 showed potent antifouling activities against the barnacle Balanus amphitrite.
\end{abstract}

Keywords: soft coral; Sinularia sp.; sinularones A-I; structural elucidation; antifouling activity 


\section{Introduction}

The genus Sinularia is a dominant biomass with about 100 known species widely distributed in the tropical reef environment [1-4], presenting a rich array of chemical diversity involving sesquiterpenes, diterpenes, polyhydroxylated steroids, and polyamine compounds. Several metabolites derived from Sinularia play an active role in chemical defense [5,6], and display a range of biological activities, such as antimicrobial [7], anti-inflammatory [8], and cytotoxic [9,10]. In the course of our search for bioactive natural products from marine invertebrates inhabited in the South China Sea, an octocoral Sinularia sp. was collected off Hainan Island. Chemical examination of the EtOAc soluble fraction of this specimen resulted in the isolation of the new cyclopentenone derivatives (1-6) and furanones (7-9), along with the known butenolide (10) (Figure 1). This paper reports the structural elucidation of the new compounds and the evaluation of their antifouling activities.

Figure 1. Structures of compounds (1-10).

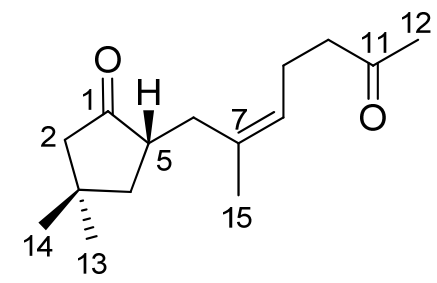

1
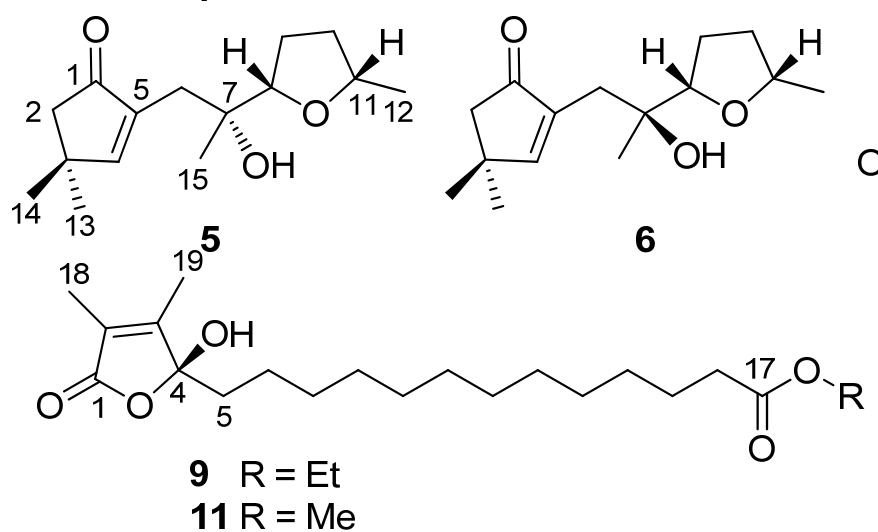

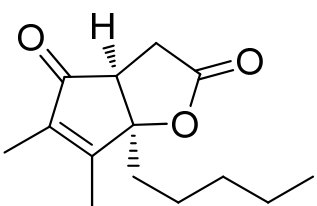

3

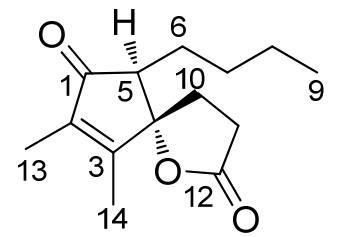

4

8

\section{Results and Discussion}

Sinularone A (1) has a molecular formula of $\mathrm{C}_{15} \mathrm{H}_{24} \mathrm{O}_{2}$ as established by the HRESIMS $\left(\mathrm{m} / z\right.$ 259.1674 $[\mathrm{M}+\mathrm{Na}]^{+}$, calcd. 259.1674) and NMR data, indicating $4^{\circ}$ unsaturation. The IR absorptions at 1738 and $1717 \mathrm{~cm}^{-1}$ suggested the presence of carbonyl groups. The ${ }^{1} \mathrm{H}$ NMR spectrum exhibited the signals for a single olefinic proton at $\delta_{\mathrm{H}} 5.12(1 \mathrm{H}, \mathrm{t}, J=7.2 \mathrm{~Hz}, \mathrm{H}-8)$, four methyl singlets at $\delta_{\mathrm{H}} 1.01\left(3 \mathrm{H}, \mathrm{s}, \mathrm{H}_{3}-13\right), 1.13\left(3 \mathrm{H}, \mathrm{s}, \mathrm{H}_{3}-14\right), 1.61\left(3 \mathrm{H}, \mathrm{s}, \mathrm{H}_{3}-15\right)$ and $2.07\left(3 \mathrm{H}, \mathrm{s}, \mathrm{H}_{3}-12\right)$, together with 11 aliphatic protons. APT spectra displayed 15 carbon resonances, involving two ketones at $\delta_{\mathrm{C}} 220.0(\mathrm{C}-1)$ and 208.5 (C-11), and two olefinic carbons at $\delta_{\mathrm{C}} 125.7$ (CH, C-8) and $133.9(\mathrm{C}, \mathrm{C}-7)$. The proton signals and their associated carbons were assigned by HMQC. The COSY cross-peaks allowed to establish the proton-proton spin systems from C-4 to C-6 and from C-8 to C-10, while the HMBC interactions from the olefinic $\mathrm{H}_{3}-15$ to $\mathrm{C}-6\left(\delta_{\mathrm{C}} 32.3\right), \mathrm{C}-7$, and $\mathrm{C}-8$, and from $\mathrm{H}_{3}-12$ to $\mathrm{C}-11$ and $\mathrm{C}-10\left(\delta_{\mathrm{C}} 43.4\right)$ led to the connectivity of the subunits to form a linear chain defined as a 
7-methylhept-7-en-11-one group (Figure 2). Additional HMBC interactions from the geminal protons $\mathrm{H}_{\alpha, \beta}-2\left(\delta_{\mathrm{H}} 2.08,2.16\right)$ to $\mathrm{C}-3\left(\delta_{\mathrm{C}} 34.0\right), \mathrm{C}-4\left(\delta_{\mathrm{C}} 43.5\right), \mathrm{C}-5\left(\delta_{\mathrm{C}} 46.7\right)$ and $\mathrm{C}-1$, along with the correlations from both $\mathrm{H}_{3}-13$ and $\mathrm{H}_{3}-14$ to $\mathrm{C}-2\left(\delta_{\mathrm{C}} 52.8\right)$, C-3, and C-4, and from $\mathrm{H}-5\left(\delta_{\mathrm{H}} 2.49, \mathrm{~m}\right)$ to $\mathrm{C}-1$ and $\mathrm{C}-3$ indicated the presence of a 3,3-dimethylcyclopentanone nucleus. Subsequently, the linear side chain was determined to be linked to the nucleus at C-5 on the basis of the COSY relationships in addition to the $\mathrm{HMBC}$ interactions from $\mathrm{H}_{2}-4\left(\delta_{\mathrm{H}} 1.41,1.84\right)$ to $\mathrm{C}-6$ and from $\mathrm{H}_{2}-6$ to $\mathrm{C}-1, \mathrm{C}-4$, and C-5. The geometry of $\Delta^{7}$ was assigned to $7 Z$ according to the NOE interaction between $\mathrm{H}_{3}-15$ and $\mathrm{H}-8$ in addition to the chemical shift of $\mathrm{C}-15\left(\delta_{\mathrm{C}} 23.5\right)$, higher than $20 \mathrm{ppm}$ [11]. In regard to the configuration of the stereogenic center $\mathrm{C}-5$, the $\mathrm{CD}$ spectrum showed a negative Cotton effect at $212 \mathrm{~nm}$ for $n-\pi^{*}$ transition in agreement with the electronic circular dichroism (ECD) data which was calculated for $5 S$ configuration by time dependent density functional theory (TD DFT) at $6-31+\mathrm{G}(d, p) / / \mathrm{DFT}$ B3LYP/6-31+G $(d, p)$ level [12]. This assignment was also supported by the octant rule which allowed the side chain to be located at the negative CD region (Figure 3) [13].

Figure 2. Key COSY, HMBC and NOE relationships of (1).

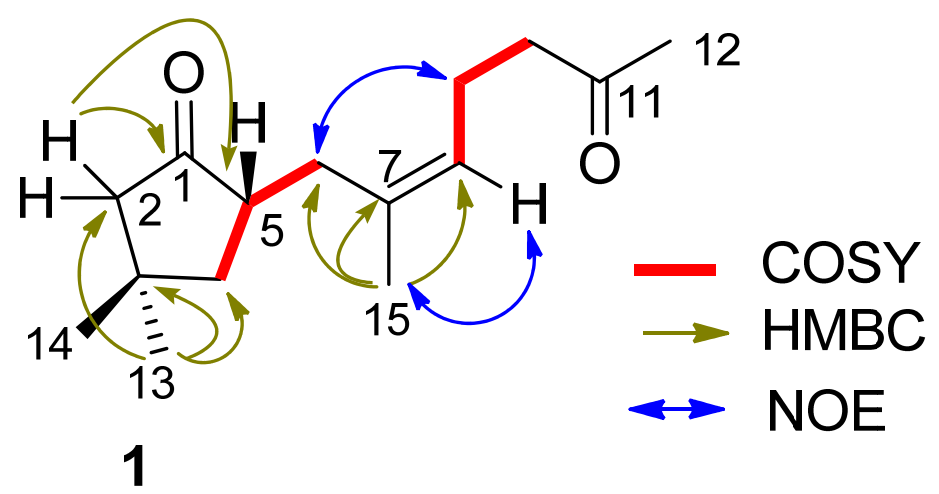

Figure 3. CD, electronic circular dichroism (ECD) and octant rule of (1).

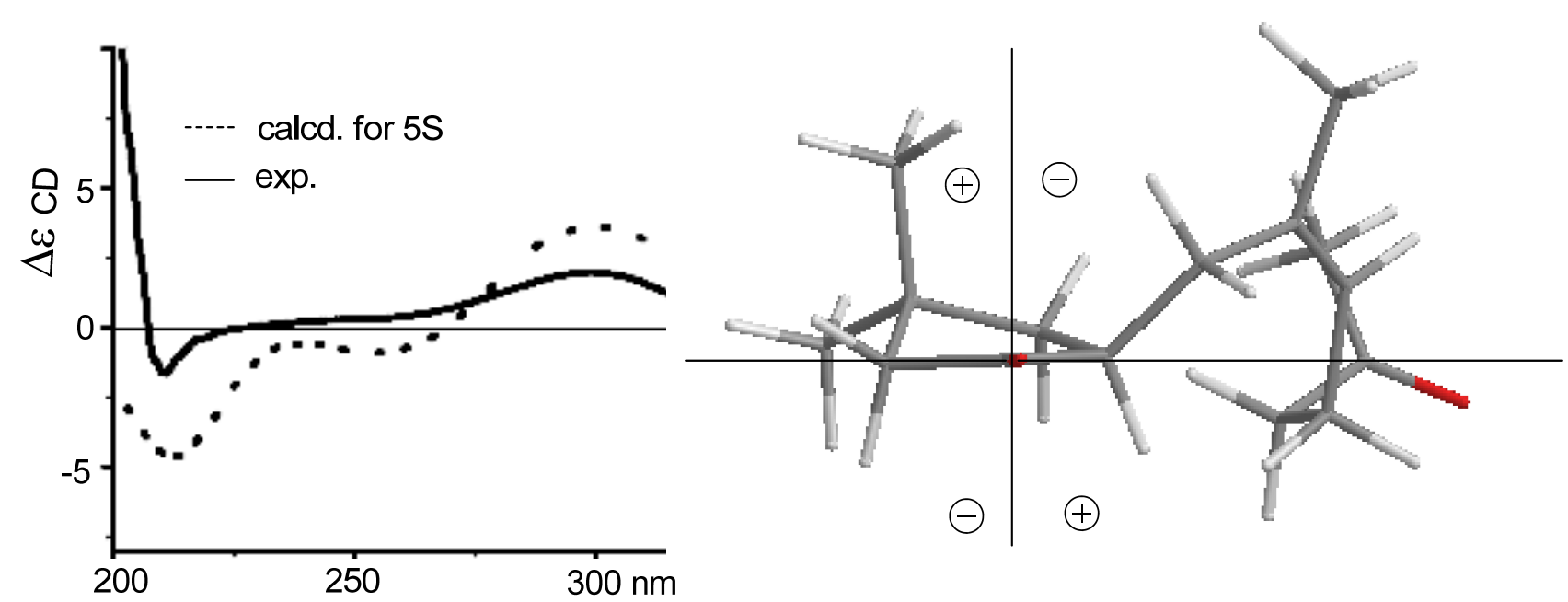

Sinularone B (2) has a molecular formula of $\mathrm{C}_{16} \mathrm{H}_{26} \mathrm{O}_{4}$ as determined by the HRESIMS $(\mathrm{m} / \mathrm{z} 305.1732$ $[\mathrm{M}+\mathrm{Na}]^{+}$, calcd. 305.1729) and NMR data, indicating $4^{\circ}$ unsaturation. The IR absorptions at 3489, 1737, 1707 and $1653 \mathrm{~cm}^{-1}$ suggested the presence of hydroxy, carbonyl, and olefinic groups. The ${ }^{1} \mathrm{H}$ NMR spectrum exhibited two terminal methyls appearing as doublets at $\delta_{\mathrm{H}} 0.80\left(3 \mathrm{H}, \mathrm{t}, J=7.0 \mathrm{~Hz}, \mathrm{H}_{3}-12\right)$ 
and $1.21\left(3 \mathrm{H}, \mathrm{t}, J=7.1 \mathrm{~Hz}, \mathrm{H}_{3}-1^{\prime}\right)$, and two olefinic methyl singlets at $\delta_{\mathrm{H}} 1.62\left(3 \mathrm{H}, \mathrm{s}, \mathrm{H}_{3}-13\right)$ and $1.90\left(3 \mathrm{H}, \mathrm{s}, \mathrm{H}_{3}-14\right)$, in addition to 13 aliphatic protons (Table 1). APT spectrum displayed a total of 16 carbon resonances, of which two carbonyl carbons, two olefinic carbons, an oxygen-bearing $\mathrm{sp}^{3}$ carbon, and an oxymethylene were observed (Table 2). The presence of a $n$-pentyl unit was recognized by the COSY and HMBC relationships to establish a side chain from C-8 to C-12, while an ethoxy group was ascribed to the COSY coupling between $\mathrm{H}_{3}-1^{\prime}$ and $\delta_{\mathrm{H}} 4.10\left(2 \mathrm{H}, \mathrm{q}, J=7.1 \mathrm{~Hz}, \mathrm{H}_{2}-2^{\prime}\right)$. In HMBC spectrum, the interactions from $\mathrm{H}_{3}-13$ to the carbons at $\delta_{\mathrm{C}} 203.8(\mathrm{C}-1), 134.3(\mathrm{C}-2)$, and 170.0 (C-3), and from $\mathrm{H}_{3}-14$ to $\mathrm{C}-2, \mathrm{C}-3$, and $\mathrm{C}-4\left(\delta_{\mathrm{C}} 80.1\right)$, in addition to the interaction from a methine proton $\delta_{\mathrm{H}} 2.89(1 \mathrm{H}, \mathrm{dd}, J=5.6,8.4, \mathrm{H}-5)$ to $\mathrm{C}-1, \mathrm{C}-2, \mathrm{C}-3$, and $\mathrm{C}-4$, conducted to establish a 2,3-dimethylcyclopent-2-enone nucleus. The COSY coupling between $\mathrm{H}-5$ and the methylene protons $\mathrm{H}_{2}-6$ at $\delta_{\mathrm{H}} 2.44(1 \mathrm{H}, \mathrm{dd}, J=5.6,16.0 \mathrm{~Hz})$ and $2.35(1 \mathrm{H}, \mathrm{dd}, J=8.4,16.0 \mathrm{~Hz})$ in association with the HMBC interaction from the carbonyl carbon $\left(\delta_{\mathrm{C}} 172.5, \mathrm{C}-7\right)$ to $\mathrm{H}-5, \mathrm{H}_{2}-6$, and the oxymethylene $\mathrm{H}_{2}-2^{\prime}$, ascertained an ethylacetate unit linked to $\mathrm{C}-5\left(\delta_{\mathrm{C}} 55.3\right)$. The oxygenated quaternary carbon $\mathrm{C}-4$ was determined to be co-positioned by a $n$-pentyl unit and a hydroxy group on the basis of the HMBC interactions between $\mathrm{H}-5$ and the methylene carbon C-8 $\left(\delta_{\mathrm{C}} 35.9\right)$, and in turn from $\mathrm{H}_{2}-8\left(\delta_{\mathrm{H}} 1.54,1.58\right)$ to $\mathrm{C}-3, \mathrm{C}-4$, and $\mathrm{C}-5$, in addition to a $\mathrm{D}_{2} \mathrm{O}$ exchangeable proton $\left(\delta_{\mathrm{H}} 5.28\right.$, s) showing $\mathrm{HMBC}$ relationship with $\mathrm{C}-4$. The NOE interaction between $\mathrm{H}_{2}-6$ and $\mathrm{H}_{2}-8\left(\delta_{\mathrm{H}} 1.54,1.58\right)$ was indicative of their cis relationship. Thus, the relative configurations of the stereogenic centers were depicted to be $4 S^{*}$ and $5 S^{*}$. The measured CD curve of 2 was closely similar to the calculated ECD for $4 S, 5 S$-isomer in opposite to the data for $4 R, 5 R$-isomer (Figure 4), indicating 2 to be in agreement with $4 S$ and $5 S$.

The NMR spectroscopic data of sinularone C (3) were closely related to those of 2, except for the absence of the signals for an ethoxy group. Analysis of 1D and 2D NMR (COSY, HMQC and HMBC) disclosed a 2,3-dimethylcyclopent-2-enone nucleus, and a $n$-pentyl group being linked to the nucleus at $\mathrm{C}-4$, showing the partial structure to be the same as that of 2 . The COSY cross-peaks between H-5 $\left(\delta_{\mathrm{H}} 3.11\right)$ and $\mathrm{H}_{2}-6\left(\delta_{\mathrm{H}} 2.49,3.08\right)$ and the $\mathrm{HMBC}$ interactions of these protons with a carbonyl carbon C-7 $\left(\delta_{\mathrm{C}} 174.9\right)$ and the ketone $\mathrm{C}-1\left(\delta_{\mathrm{C}} 204.9\right)$ allowed to link C-6 of an acetyl unit to cyclopent-2-enone nucleus at C-5. In addition, a quaternary carbon observed at $\delta_{\mathrm{C}} 92.4$ was assigned to $\mathrm{C}-4$ on the basis of the HMBC interactions of $\mathrm{C}-4$ to $\mathrm{H}-5$ and $\mathrm{H}_{2}-6$. The molecular formula $\left(\mathrm{C}_{14} \mathrm{H}_{20} \mathrm{O}_{3}\right)(\mathrm{HRESIMS}$ $m / z 259.1315[\mathrm{M}+\mathrm{Na}]^{+}$) of $\mathbf{3}$ showing a $\mathrm{C}_{2} \mathrm{H}_{6} \mathrm{O}$ unit less than that of $\mathbf{2}$ and requiring $5^{\circ}$ unsaturation, in association with the obvious downfield shifted $\mathrm{C}-4$ in comparison with that of $\mathbf{2}$, allowed to connect C-4 and C-7 to form a $\gamma$-lactone, which was fused to the cyclopentenone ring across C-4 and C-5. The observed NOE interactions from $\mathrm{H}-5$ to $\mathrm{H}_{2}-8\left(\delta_{\mathrm{H}} 1.79,1.97\right)$ and $\mathrm{H}_{2}-9\left(\delta_{\mathrm{H}} 1.10,1.16\right)$ indicated $\mathrm{H}-5$ to be oriented in the same face as $n$-pentyl group. This assignment was supported by the irradiation of $\mathrm{H}_{2}-8$ causing the NOE enhancement of $\mathrm{H}-5$ (1.7\%, 1.2\%). Compound 3 is likely a precursor to generate 2 by ethoxylation. Thus, the absolute configuration of C-5 in $\mathbf{3}$ is suggested to be the same as that of $\mathbf{2}$. Accordingly, the chiral centers of $\mathbf{3}$ were assumed to be $4 R$ and $5 S$. 
Table 1. ${ }^{1} \mathrm{H}$ NMR data of sinulactones A-H (1-8) $\left(500 \mathrm{MHz}, \delta_{\mathrm{H}}, J\right.$ in $\left.\mathrm{Hz}\right)$.

\begin{tabular}{|c|c|c|c|c|c|c|c|c|}
\hline No. & $1^{a}$ & $2^{a}$ & $3^{a}$ & $4^{\mathrm{a}}$ & $5^{a}$ & $6^{a}$ & $7^{a}$ & $8^{b}$ \\
\hline \multirow[t]{2}{*}{2} & $2.08 \mathrm{~d}(16.4)$ & & & & $2.18 \mathrm{~s}$ & $2.18 \mathrm{~d}(18.0)$ & & \\
\hline & $2.16 \mathrm{~d}(16.4)$ & & & & $2.18 \mathrm{~s}$ & $2.22 \mathrm{~d}(18.0)$ & & \\
\hline \multirow{2}{*}{4} & $1.41 \mathrm{dd}(11.5,12.4)$ & & & & $7.35 \mathrm{~s}$ & $7.35 \mathrm{~s}$ & & \\
\hline & $1.84 \mathrm{dd}(8.4,12.4)$ & & & & & & & \\
\hline \multirow{2}{*}{5} & $2.49 \mathrm{~m}$ & $2.89 \mathrm{dd}(5.6,8.4)$ & $3.11 \mathrm{dd}(5.5,10.2)$ & $2.55 \mathrm{t}(6.5)$ & & & $1.91 \mathrm{ddd}(6.0,6.0,17.0)$ & $1.97 \operatorname{ddd}(7.8,7.8,15.5)$ \\
\hline & & & & & & & 2.32 ddd $(6.0,8.0,17.0)$ & $2.22 \mathrm{~m}$ \\
\hline \multirow{2}{*}{6} & $2.06 \mathrm{~m}$ & $2.35 \mathrm{dd}(8.4,16.0)$ & $2.49 \mathrm{dd}(10.2,15.5)$ & $1.45 \mathrm{~m}$ & $2.09 \mathrm{~d}(13.9)$ & $2.21 \mathrm{~s}$ & $2.49 \mathrm{ddd}(6.0,6.0,18.0)$ & $2.24 \mathrm{~m}$ \\
\hline & $2.29 \mathrm{dd}(4.2,13.4)$ & $2.44 \mathrm{dd}(5.6,16.0)$ & $3.08 \mathrm{dd}(5.5,15.5)$ & $1.67 \mathrm{~m}$ & $2.27 \mathrm{~d}(13.9)$ & $2.21 \mathrm{~s}$ & $2.78 \mathrm{ddd}(6.0,8.0,18.0)$ & $2.27 \mathrm{~m}$ \\
\hline \multirow{2}{*}{7} & & & & $1.30 \mathrm{~m}$ & & & & \\
\hline & & & & $1.46 \mathrm{~m}$ & & & & \\
\hline \multirow{2}{*}{8} & $5.12 \mathrm{t}(7.2)$ & $1.54 \mathrm{ddd}(4.0,11.0,12.0)$ & 1.79 ddd $(4.7,12.1,13.5)$ & $1.30 \mathrm{~m}$ & $3.57 \mathrm{t}(7.2)$ & $3.56 \mathrm{dd}(7.4,7.4)$ & $1.80 \mathrm{~s}$ & $1.77 \mathrm{~s}$ \\
\hline & & $1.58 \mathrm{ddd}(5.5,11.0,12.0)$ & $1.97 \mathrm{ddd}(4.5,12.1,13.5)$ & $1.32 \mathrm{~m}$ & & & & \\
\hline \multirow{2}{*}{9} & $2.16 \mathrm{ddt}(7.2,7.4,12.0)$ & $0.53 \mathrm{~m}$ & $1.10 \mathrm{~m}$ & $0.88 \mathrm{t}(7.2)$ & $1.75 \mathrm{~m}$ & $1.71 \mathrm{~m}$ & $1.96 \mathrm{~s}$ & $1.87 \mathrm{~s}$ \\
\hline & $2.19 \mathrm{ddt}(7.2,7.4,12.0)$ & $0.66 \mathrm{~m}$ & $1.16 \mathrm{~m}$ & & $1.80 \mathrm{~m}$ & $1.78 \mathrm{~m}$ & & \\
\hline \multirow{2}{*}{10} & $2.44 \mathrm{dd}(7.4,7.4)$ & $1.15 \mathrm{~m}$ & $1.29 \mathrm{~m}$ & 2.16 ddd $(7.7,10.6,13.9)$ & $1.27 \mathrm{~m}$ & $1.30 \mathrm{~m}$ & & \\
\hline & & & & $2.23 \mathrm{ddd}(6.2,10.3,13.9)$ & $1.87 \mathrm{~m}$ & $1.87 \mathrm{~m}$ & & \\
\hline \multirow{2}{*}{11} & & $1.18 \mathrm{~m}$ & $1.29 \mathrm{~m}$ & 2.72 ddd $(7.7,10.3,18.4)$ & $3.83 \mathrm{~m}$ & $3.86 \mathrm{~m}$ & & \\
\hline & & & & 2.78 ddd $(6.2,10.6,18.4)$ & & & & \\
\hline 12 & $2.07 \mathrm{~s}$ & $0.80 \mathrm{t}(7.0)$ & $0.86 \mathrm{t}(7.1)$ & & $1.13 \mathrm{~d}(6.0)$ & $1.14 \mathrm{~d}(6.0)$ & & \\
\hline 13 & $1.01 \mathrm{~s}$ & $1.62 \mathrm{~s}$ & $1.67 \mathrm{~s}$ & $1.65 \mathrm{~s}$ & $1.15 \mathrm{~s}$ & $1.15 \mathrm{~s}$ & & \\
\hline 14 & $1.13 \mathrm{~s}$ & $1.90 \mathrm{~s}$ & $2.02 \mathrm{~s}$ & $1.97 \mathrm{~s}$ & $1.15 \mathrm{~s}$ & $1.15 \mathrm{~s}$ & & \\
\hline 15 & $1.61 \mathrm{~s}$ & & & & $0.87 \mathrm{~s}$ & $0.84 \mathrm{~s}$ & & \\
\hline \multirow{4}{*}{ EtO } & & $4.10 \mathrm{q}(7.1)$ & & & & & $4.17 \mathrm{q}(7.1)$ & $3.13 \mathrm{dq}(7.0,12.0)$ \\
\hline & & $1.21 \mathrm{t}(7.1)$ & & & & & $1.27 \mathrm{t}(7.1)$ & $3.24 \mathrm{dq}(7.0,12.0)$ \\
\hline & & & & & & & & $1.09 \mathrm{t}(7.0)$ \\
\hline & & & & & & & & $3.58 \mathrm{~s}$ \\
\hline $\mathrm{OH}-4$ & & $5.28 \mathrm{~s}$ & & & & & $5.26 \mathrm{~s}$ & \\
\hline $\mathrm{OH}-7$ & & & & & $4.16 \mathrm{~s}$ & $4.16 \mathrm{~s}$ & & \\
\hline
\end{tabular}


Table 2. ${ }^{13} \mathrm{C}$ NMR data of sinulactones A-H (1-8) $\left(125 \mathrm{MHz}, \delta_{\mathrm{C}}\right.$, mult.).

\begin{tabular}{|c|c|c|c|c|c|c|c|c|}
\hline No. & $1^{a}$ & $2^{a}$ & $3^{a}$ & $4^{a}$ & $5^{a}$ & $6^{a}$ & $7^{a}$ & $8^{b}$ \\
\hline 1 & $220.0 \mathrm{C}$ & $203.8 \mathrm{C}$ & $204.9 \mathrm{C}$ & $203.4 \mathrm{C}$ & $209.4 \mathrm{C}$ & $209.4 \mathrm{C}$ & $171.8 \mathrm{C}$ & $171.1 \mathrm{C}$ \\
\hline 2 & $52.8 \mathrm{CH}_{2}$ & $134.3 \mathrm{C}$ & $138.7 \mathrm{C}$ & $136.4 \mathrm{C}$ & $49.8 \mathrm{CH}_{2}$ & $49.8 \mathrm{CH}_{2}$ & $124.7 \mathrm{C}$ & $127.1 \mathrm{C}$ \\
\hline 3 & $34.0 \mathrm{C}$ & $170.0 \mathrm{C}$ & $166.7 \mathrm{C}$ & $164.9 \mathrm{C}$ & $38.9 \mathrm{C}$ & $38.9 \mathrm{C}$ & $158.2 \mathrm{C}$ & $156.7 \mathrm{C}$ \\
\hline 4 & $43.5 \mathrm{CH}_{2}$ & $80.1 \mathrm{C}$ & $92.4 \mathrm{C}$ & $91.5 \mathrm{C}$ & $170.8 \mathrm{C}$ & $170.7 \mathrm{C}$ & $105.5 \mathrm{C}$ & $109.1 \mathrm{C}$ \\
\hline 5 & $46.7 \mathrm{CH}$ & $55.3 \mathrm{CH}$ & $46.4 \mathrm{CH}$ & $54.5 \mathrm{CH}$ & $138.8 \mathrm{C}$ & $138.9 \mathrm{C}$ & $31.3 \mathrm{CH}_{2}$ & $31.3 \mathrm{CH}_{2}$ \\
\hline 6 & $32.3 \mathrm{CH}_{2}$ & $29.6 \mathrm{CH}_{2}$ & $32.3 \mathrm{CH}_{2}$ & $24.8 \mathrm{CH}_{2}$ & $33.5 \mathrm{CH}_{2}$ & $32.2 \mathrm{CH}_{2}$ & $28.9 \mathrm{CH}_{2}$ & $28.0 \mathrm{CH}_{2}$ \\
\hline 7 & $133.9 \mathrm{C}$ & $172.5 \mathrm{C}$ & $174.9 \mathrm{C}$ & $29.3 \mathrm{CH}_{2}$ & $72.5 \mathrm{C}$ & $72.3 \mathrm{C}$ & $174.8 \mathrm{C}$ & $172.9 \mathrm{C}$ \\
\hline 8 & $125.7 \mathrm{CH}$ & $35.9 \mathrm{CH}_{2}$ & $34.0 \mathrm{CH}_{2}$ & $22.2 \mathrm{CH}_{2}$ & $85.2 \mathrm{CH}$ & $85.2 \mathrm{CH}$ & $8.4 \mathrm{CH}_{3}$ & $8.6 \mathrm{CH}_{3}$ \\
\hline 9 & $22.3 \mathrm{CH}_{2}$ & $24.6 \mathrm{CH}_{2}$ & $23.0 \mathrm{CH}_{2}$ & $13.7 \mathrm{CH}_{3}$ & $26.2 \mathrm{CH}_{2}$ & $26.1 \mathrm{CH}_{2}$ & $10.6 \mathrm{CH}_{3}$ & $11.0 \mathrm{CH}_{3}$ \\
\hline 10 & $43.4 \mathrm{CH}_{2}$ & $31.9 \mathrm{CH}_{2}$ & $31.7 \mathrm{CH}_{2}$ & $25.3 \mathrm{CH}_{2}$ & $33.3 \mathrm{CH}_{2}$ & $33.2 \mathrm{CH}_{2}$ & & \\
\hline 11 & $208.5 \mathrm{C}$ & $22.3 \mathrm{CH}_{2}$ & $22.3 \mathrm{CH}_{2}$ & $28.7 \mathrm{CH}_{2}$ & $75.3 \mathrm{CH}$ & $75.2 \mathrm{CH}$ & & \\
\hline 12 & $30.2 \mathrm{CH}_{3}$ & $14.3 \mathrm{CH}_{3}$ & $14.3 \mathrm{CH}_{3}$ & $176.1 \mathrm{C}$ & $21.3 \mathrm{CH}_{3}$ & $21.4 \mathrm{CH}_{3}$ & & \\
\hline 13 & $28.1 \mathrm{CH}_{3}$ & $8.0 \mathrm{CH}_{3}$ & $8.3 \mathrm{CH}_{3}$ & $7.8 \mathrm{CH}_{3}$ & $28.6 \mathrm{CH}_{3}$ & $28.5 \mathrm{CH}_{3}$ & & \\
\hline 14 & $29.9 \mathrm{CH}_{3}$ & $11.6 \mathrm{CH}_{3}$ & $12.3 \mathrm{CH}_{3}$ & $10.6 \mathrm{CH}_{3}$ & $28.4 \mathrm{CH}_{3}$ & $28.5 \mathrm{CH}_{3}$ & & \\
\hline 15 & $23.5 \mathrm{CH}_{3}$ & & & & $21.9 \mathrm{CH}_{3}$ & $23.4 \mathrm{CH}_{3}$ & & \\
\hline \multicolumn{9}{|l|}{16} \\
\hline \multicolumn{9}{|l|}{17} \\
\hline \multicolumn{9}{|l|}{18} \\
\hline EtO & & $14.5 \mathrm{CH}_{3}$ & & & & & $14.1 \mathrm{CH}_{3}$ & $15.4 \mathrm{CH}_{3}$ \\
\hline & & $60.5 \mathrm{CH}_{2}$ & & & & & $61.5 \mathrm{CH}_{2}$ & $58.4 \mathrm{CH}_{2}$ \\
\hline $\mathrm{MeO}$ & & & & & & & & $51.9 \mathrm{CH}_{3}$ \\
\hline
\end{tabular}

${ }^{\mathrm{a}}$ In DMSO- $d_{6},{ }^{\mathrm{b}}$ In $\mathrm{CDCl}_{3}$.

Figure 4. CD and ECD spectra of (2).
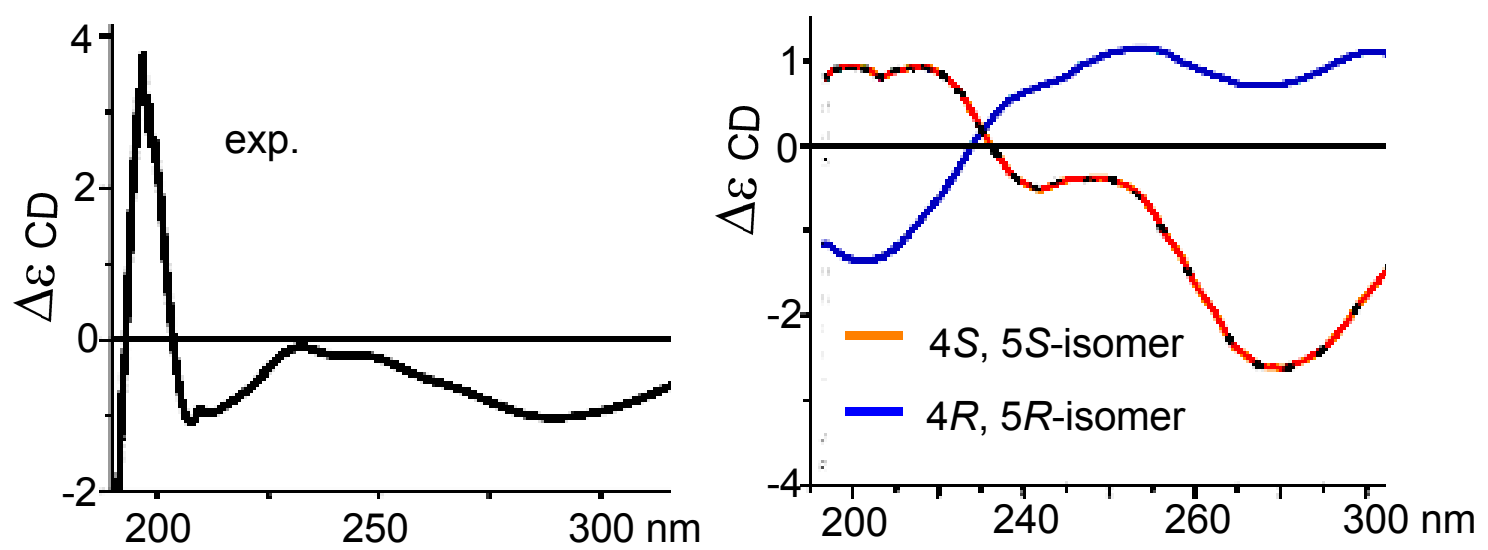

The molecular formula $\left(\mathrm{C}_{14} \mathrm{H}_{20} \mathrm{O}_{3}\right)$ of sinularone $\mathrm{D}(4)$ was determined to be the same as that of 3 on the basis of the HRESIMS data $(\mathrm{m} / z \text { 259.1313 [M + Na] }]^{+}$, calcd. 259.1310) and NMR data. The IR absorptions at 1778,1710 and $1657 \mathrm{~cm}^{-1}$ were characteristic of lactone, ketone, and olefinic groups. Comparison of the NMR data revealed the resonances of 4 in respect to those of a 2,3-dimethylcyclopent-2-enone nucleus (Tables 1 and 2) compatible to the data of $\mathbf{3}$. However, the COSY and HMBC relationships revealed a $n$-butyl group to replace a $n$-pentyl group of $\mathbf{3}$. This unit was determined to be linked to $\mathrm{C}-5\left(\delta_{\mathrm{C}} 54.5\right)$ as evident from the COSY correlation between $\mathrm{H}_{2}-6$ $\left(\delta_{\mathrm{H}} 1.45,1.67\right)$ and $\mathrm{H}-5\left(\delta_{\mathrm{H}} 2.55, \mathrm{t}, J=6.5 \mathrm{~Hz}\right)$ in association with the $\mathrm{HMBC}$ interactions from $\mathrm{H}_{2}-6$ to 
$\mathrm{C}-1\left(\delta_{\mathrm{C}} 203.4\right)$. The remaining resonances included two methylenes and a carbonyl carbon $\left(\delta_{\mathrm{C}} 176.1\right.$, C-12). The COSY correlation between $\mathrm{H}_{2}-10\left(\delta_{\mathrm{H}} 2.16,2.23\right)$ and $\mathrm{H}_{2}-11\left(\delta_{\mathrm{H}} 2.72,2.78\right)$ and the HMBC interactions from $\mathrm{H}_{2}-10$ to $\mathrm{C}-12$ and from $\mathrm{H}_{2}-11$ to $\mathrm{C}-4\left(\delta_{\mathrm{C}} 91.5, \mathrm{C}\right)$, in association with the molecular formula requiring $5^{\circ}$ unsaturation, conducted the quaternary carbon $\mathrm{C}-4$ to be located by a $\gamma$-lactone. The NOE interaction between $\mathrm{H}_{2}-6$ and $\mathrm{H}_{2}-10$ reflected the same orientation of $\mathrm{H}-5$ and the heterocyclic atom of lactone. In regard to the absolute configuration of the spiro carbon C-4, we extended the CD method originally used for the chiral center of allylic amines [14]. The negative Cotton effect at $222 \mathrm{~nm}$ belonging to the $\pi-\pi^{*}$ charge-transfer transition polarized by the lactone carbonyl group and the enone unit, correlated with anti-clockwise screw (Figure 5). Therefore, the sign of the Cotton effect reflected a $4 R$ configuration. In combination with NOE data, C-5 was thus assigned to $S$ configuration.

Figure 5. Cotton effect of (4).

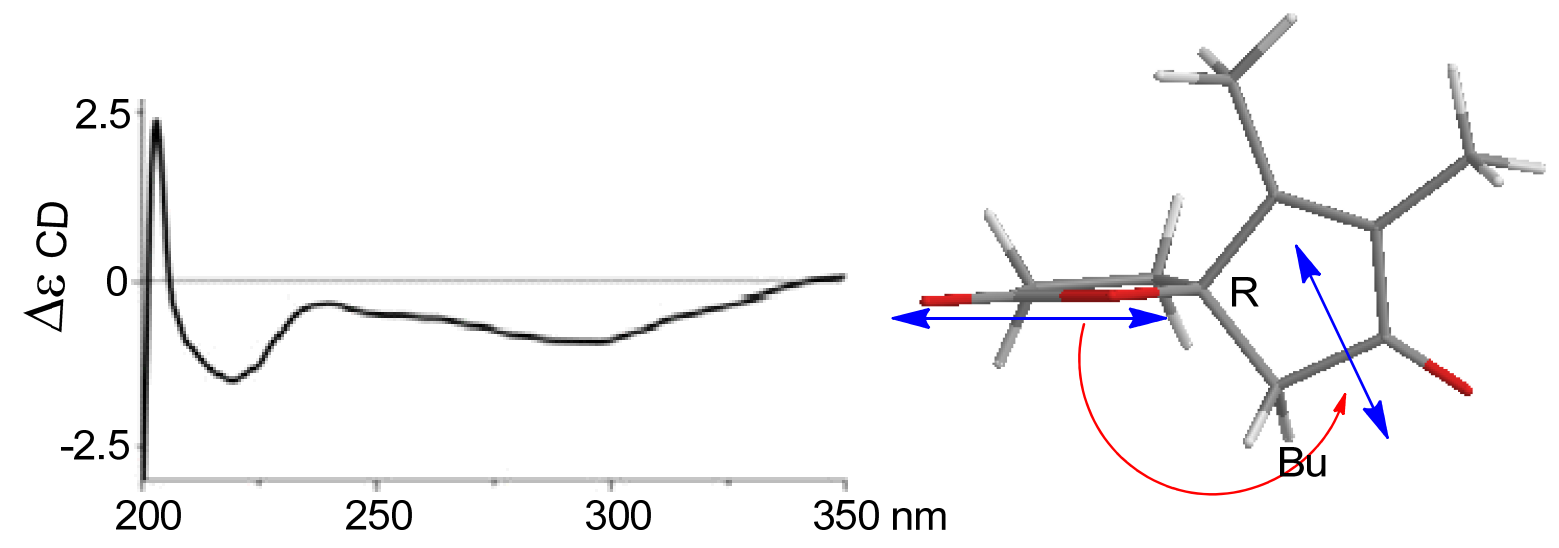

The NMR spectroscopic data of $\mathbf{5}$ and $\mathbf{6}$ are very similar, while HRESIMS data revealed both compounds shared the same molecular formula $\left(\mathrm{C}_{15} \mathrm{H}_{24} \mathrm{O}_{3}\right)$, indicating $4^{\circ}$ unsaturation. APT spectrum of 5 displayed 15 carbon resonances, involving one ketone $\left(\delta_{\mathrm{C}} 209.4, \mathrm{C}-1\right)$, two olefinic carbons $\left(\delta_{\mathrm{C}} 138.8, \mathrm{C}-5 ; 170.8, \mathrm{C}-4\right)$, two oxymethines at $\delta_{\mathrm{C}} 85.2(\mathrm{C}-8)$ and $75.3(\mathrm{C}-11)$ and four methyls $\left(\delta_{\mathrm{C}} 21.3,21.9,28.4,28.6\right)$. The observation of HMBC interactions from the isolated methylene protons at $\delta_{\mathrm{H}} 2.18\left(2 \mathrm{H}, \mathrm{s}, \mathrm{H}_{2}-2\right)$ to $\mathrm{C}-1, \mathrm{C}-3\left(\delta_{\mathrm{C}} 38.9, \mathrm{C}\right), \mathrm{C}-4$, and $\mathrm{C}-5$ and from $\mathrm{H}-4\left(\delta_{\mathrm{H}} 7.35, \mathrm{~s}\right)$ to $\mathrm{C}-1, \mathrm{C}-2$, and $\mathrm{C}-3$, in addition to the methyl singlets at $\delta_{\mathrm{H}} 1.15\left(6 \mathrm{H}, \mathrm{s}, \mathrm{H}_{3}-13\right.$ and $\left.\mathrm{H}_{3}-14\right)$ to $\mathrm{C}-2, \mathrm{C}-3$, and $\mathrm{C}-4$, ascertained the presence of 5-substituted 3,3-dimethylcyclopent-4-enone. In regard to the remaining resonances, the COSY correlations extended a moiety from $\mathrm{C}-8$ to $\mathrm{C}-12$, in which $\mathrm{C}-8$ and $\mathrm{C}-11$ were oxygenated. Additionally, the HMBC interactions from $\mathrm{H}_{3}-15\left(\delta_{\mathrm{H}} 0.87, \mathrm{~s}\right)$ to the methylene carbon C-6 $\left(\delta_{\mathrm{C}} 33.5\right)$, quaternary carbon $\mathrm{C}-7\left(\delta_{\mathrm{C}} 72.5\right)$ and $\mathrm{C}-8$ and from $\mathrm{H}-8\left(\delta_{\mathrm{H}} 3.57, \mathrm{t}, J=7.2 \mathrm{~Hz}\right)$ to C-11 indicated the formation of an ether bridge across $\mathrm{C}-8$ and $\mathrm{C}-11$, while $\mathrm{C}-7$ was co-positioned by a methyl and a hydroxy groups. The side chain was linked to $\mathrm{C}-5$ as evident from the HMBC relationships of $\mathrm{H}_{2}-6\left(\delta_{\mathrm{H}} 2.09,2.27\right)$ with $\mathrm{C}-1, \mathrm{C}-5$, and $\mathrm{C}-4$. Based on the NOE interaction between $\mathrm{H}-8$ and H-11, a cis-geometry of the 8,11-epoxy bonding was assigned. Thus, the relative configurations were suggested to be $8 S^{*}$ and $11 S^{*}$.

Analysis of 2D NMR data revealed sinularone F (6) to be a stereoisomer of 5. Both compounds showed the NOE interaction between $\mathrm{H}-8$ and H-11, indicating them to be oriented in the same face 
toward tetrahydrofuran ring. The major difference was found by the chemical shifts at C-6 and C-15 (Table 2), implying 6 to be a C-7 epimer of 5 rather than an enantiomer. Since the calculated ECD data could not provide confidential evidence to judge the configurations, the calculation for specific rotation and ${ }^{13} \mathrm{C}$ NMR data was performed. The conformations with relative energies from 0 to $2.5 \mathrm{kcal} / \mathrm{mol}$ were used in optical rotation computations at B3LYP/6-311+G(2d,p) level, while Boltzmann statistics were used for rotation computations of all conformations. The computed specific rotation [15] for $7 S, 8 R, 11 R$-isomer is -16.9 and -27.5 for $7 R, 8 R, 11 R$-isomer. These data are in opposite sign to the experimental data that of $5\left([\alpha]_{\mathrm{D}}^{23}+18.0\right)$ and $\mathbf{6}\left([\alpha]_{\mathrm{D}}^{23}+22.6\right)$, indicating 5 and $\mathbf{6}$ to be the enantiomers of the calculated isomers. These assignments were also supported by the relative shift errors of the experimental ${ }^{13} \mathrm{C}$ NMR data of $\mathbf{6}$ and $\mathbf{5}$ that were in accordance with the error distribution calculated at B3LYP/6-311+G(2d,p) level (Table 3) [16]. Thus, the absolute configurations of 5 were in agreement with $7 R, 8 S, 11 S$, whereas those of 6 were assigned to $7 S, 8 S, 11 S$.

Table 3. The error patents of ${ }^{13} \mathrm{C}$ NMR data of $\mathbf{6}$ and $\mathbf{5}$ in experiments and computations.

\begin{tabular}{ccccccc}
\hline Position & $\mathbf{6}$ & $\mathbf{5}$ & $\mathbf{\Delta} \boldsymbol{\delta}_{\mathbf{6}-\mathbf{5}}$ & $\mathbf{6}^{*}$ & $\mathbf{5} *$ & $\boldsymbol{\Delta}_{\boldsymbol{6} \mathbf{5}}$ \\
\hline 1 & 209.4 & 209.4 & 0.0 & 206.0 & 205.8 & 0.2 \\
2 & 49.8 & 49.8 & 0.0 & 49.2 & 49.2 & 0.0 \\
3 & 38.9 & 38.9 & 0.0 & 41.9 & 42.0 & -0.1 \\
4 & 170.7 & 170.8 & -0.1 & 171.2 & 171.1 & 0.1 \\
5 & 138.9 & 138.8 & 0.1 & 142.8 & 142.5 & 0.3 \\
6 & 32.2 & 33.5 & -1.3 & 32.7 & 39.8 & -7.1 \\
7 & 72.3 & 72.5 & -0.2 & 72.4 & 72.7 & -0.3 \\
8 & 85.2 & 85.2 & 0.0 & 84.8 & 84.1 & 0.7 \\
9 & 26.1 & 26.2 & -0.1 & 27.2 & 27.4 & -0.2 \\
10 & 33.2 & 33.3 & -0.1 & 34.3 & 34.7 & -0.4 \\
11 & 75.2 & 75.3 & -0.1 & 75.7 & 75.8 & -0.1 \\
12 & 21.4 & 21.3 & 0.1 & 18.5 & 18.6 & -0.1 \\
13 & 28.5 & 28.6 & -0.1 & 26.2 & 26.4 & -0.2 \\
14 & 28.5 & 28.4 & 0.1 & 26.2 & 26.2 & 0.0 \\
15 & 23.4 & 21.9 & 1.5 & 24.4 & 17.4 & 7.0 \\
\hline
\end{tabular}

$6 *$ : calculated for $7 S, 8 S, 11 S$-isomer; $5 *$ : calculated for $7 R, 8 S, 11 S$-isomer.

Sinularone $\mathrm{G}$ (7) has a molecular formula of $\mathrm{C}_{11} \mathrm{H}_{16} \mathrm{O}_{5}$ as determined by HRESIMS data $\left(\mathrm{m} / \mathrm{z} 251.0886[\mathrm{M}+\mathrm{Na}]^{+}\right.$, calcd. 251.0895), requiring $4^{\circ}$ unsaturation. The ${ }^{1} \mathrm{H}$ NMR exhibited two olefinic methyl singlets at $\delta_{\mathrm{H}} 1.80\left(3 \mathrm{H}, \mathrm{s}, \mathrm{H}_{3}-8\right)$ and $1.96\left(3 \mathrm{H}, \mathrm{s}, \mathrm{H}_{3}-9\right)$ and a methyl triplet $\left(\delta_{\mathrm{H}} 1.27\right.$, $\mathrm{H}_{3}-1^{\prime}$ ), while ${ }^{13} \mathrm{C}$ NMR involved two carbonyl carbons at $\delta_{\mathrm{C}} 171.8(\mathrm{C}-1)$ and 174.8 (C-7), two olefinic carbons at $\delta_{\mathrm{C}} 124.7(\mathrm{C}-2)$ and $158.2(\mathrm{C}-3)$, and an acetal carbon at $\delta_{\mathrm{C}} 105.5(\mathrm{C}-4)$. The HMBC interactions of $\mathrm{H}_{3}-8$ to $\mathrm{C}-1, \mathrm{C}-2$, and $\mathrm{C}-3$ and from $\mathrm{H}_{3}-9$ to $\mathrm{C}-2, \mathrm{C}-3$, and $\mathrm{C}-4$ disclosed a $\alpha, \beta$-unsaturated 2,3-dimethyl- $\gamma$-lactone, the same as that of a known butenolide [17]. In addition, an ethylpropanoate was recognized by the COSY relationships between two vicinal methylenes along with a methyl triplet $\mathrm{H}_{3}-1^{\prime}$ coupled to the oxymethylene at $\delta_{\mathrm{H}} 4.17\left(\mathrm{H}_{2}-2^{\prime}\right)$, in combination with the $\mathrm{HMBC}$ interactions from $\mathrm{C}-7$ to the protons of $\mathrm{H}_{2}-6\left(\delta_{\mathrm{H}} 2.49,2.78\right), \mathrm{H}_{2}-5\left(\delta_{\mathrm{H}} 1.91,2.32\right)$, and the oxymethylene $\left(\delta_{\mathrm{C}} 61.5\right)$. The positive specific rotation $\left([\alpha]_{\mathrm{D}}+4.03^{\circ}\right)$ and the similar Cotton effect in comparison with those of a known butenolide (11) supposed C-4 to be $4 S$ configuration [11,17]. 
The NMR data of sinularone $\mathrm{H}(\mathbf{8})$ were similar to those of 7 with the exception of the presence of an additional methoxy group. Examination of the HMBC cross-peaks afforded the interactions between the carbonyl carbon $\left(\delta_{\mathrm{C}} 172.9, \mathrm{C}-7\right)$ and the methoxy protons $\left(\delta_{\mathrm{H}} 3.58, \mathrm{~s}\right)$ and between the acetal carbon $\left(\delta_{\mathrm{C}} 109.1, \mathrm{C}-4\right)$ and the oxymethylene $\left(\delta_{\mathrm{H}} 3.13,3.24\right)$, requiring the formation of a methyl ester, while the ethoxy group was substituted to C-4. The absolute configuration of C-4 was supposed to be the same as that of 7 on the basis of similar specific rotation and CD data.

The NMR data of sinularone I (9) were mostly identical to those of a known butenolide (11) [17]. The distinction was attributed to the presence of an ethyl ester to replace a methyl ester of the known analogue, as evident from the molecular weight of $9\left(\mathrm{C}_{21} \mathrm{H}_{36} \mathrm{O}_{5}\right)$ to be $14 \mathrm{amu}$ more than that of the latter, and the presence of an ethoxy group in its NMR spectra. The absolute configuration was determined to be $4 S$ on the basis of the similar specific rotation and Cotton effect as those of 8 and the known analogues [17].

In addition, the spectroscopic data and the specific rotation indicated the butenolide $\mathbf{1 0}$ to be identical to $(S)$-4-hydroxy-2,3-dimethyl-4-pentyl- $\gamma$-lactone, isolated from the fruiting bodies of a fungus [11].

All compounds were tested for their cytotoxicity against a panel of tumor cell lines including human ovarian carcinoma A2780, human lung adenocarcinoma A549, human gastric carcinoma BGC823, human hepatoma Bel7402, and human colonic carcinoma HCT-8. However, they showed weak inhibitory activity with $\mathrm{IC}_{50}>10 \mu \mathrm{g} / \mathrm{mL}$. In order to detect whether these compounds play a role for ecological functions, the test for antifouling activity against the larvae of the barnacle Balanus amphitrite was performed [18,19]. The bioassay results revealed compounds $\mathbf{1}-\mathbf{2}, \mathbf{7}-\mathbf{1 0}$ showed potent inhibition with the $\mathrm{EC}_{50}$ values (Table 4) lower than the standard requirement $\left(\mathrm{EC}_{50}<25 \mu \mathrm{g} / \mathrm{mL}\right)$ in regard to the efficacy level of natural antifouling agents as established by the US navy program [20]. However, compounds 3-6 showed weak inhibition with $\mathrm{EC}_{50}>50 \mu \mathrm{g} / \mathrm{mL}$. In addition, the bioactive compounds (1-2, 7-10) showed weak toxicity against the barnacle with $\mathrm{LC}_{50}>50 \mu \mathrm{g} / \mathrm{mL}$. A primary discussion of structure-activity relationship implied that $\alpha, \beta$-unsaturated 2,3 -dimethyl- $\gamma$-lactone is a functional unit for anti-barnacle. Among the active compounds, $\mathbf{1 0}$ is the most active, suggesting it to be a promising candidate as a nontoxic natural antifouling agent.

Table 4. Antifouling activity of compounds against the larvae of barnacle B. amphitrite *.

\begin{tabular}{lccc}
\hline \multirow{2}{*}{ Compounds } & \multicolumn{3}{c}{ Balanus amphitrite Larvae } \\
\cline { 2 - 4 } & $\mathbf{E C}_{\mathbf{5 0}}(\boldsymbol{\mu g} / \mathbf{m L})$ & $\mathbf{L C}_{\mathbf{5 0}}(\boldsymbol{\mu g} / \mathbf{m L})$ & $\mathbf{L C}_{\mathbf{5 0}} / \mathbf{E C}_{\mathbf{5 0}}$ \\
\hline $\mathbf{1}$ & 13.86 & $>50$ & $>3.61$ \\
$\mathbf{2}$ & 23.50 & $>50$ & $>2.13$ \\
$\mathbf{7}$ & 18.65 & $>50$ & $>2.69$ \\
$\mathbf{8}$ & 21.39 & $>50$ & $>2.34$ \\
$\mathbf{9}$ & 12.58 & $>50$ & $>3.97$ \\
$\mathbf{1 0}$ & 3.84 & $>50$ & $>13.02$ \\
\hline
\end{tabular}

$* \mathrm{EC}_{50}$ represents the concentration of a compound where $50 \%$ of larval population was inhibited to settle compared to control, while $\mathrm{LC}_{50}$ represents the concentration of a compound required to kill $50 \%$ of larvae of a tested population. 


\section{Experimental Section}

\subsection{General}

Optical rotations were measured on a Perkin-Elmer 243B polarimeter. IR spectra were determined on a Thermo Nicolet Nexus 470 FTIR spectrometer. CD spectra were measured using J-810-150s spectropolarimeter (Jasco, Darmstadt, Germany). ${ }^{1} \mathrm{H}$ and ${ }^{13} \mathrm{C}$ NMR and 2D NMR spectra were recorded on a Bruker Avance $600 \mathrm{MHz}$ and Bruker Avance $500 \mathrm{MHz}$ using TMS as an internal standard. HRESIMS data were obtained on a LTQ Orbitrap XL instrument. HPLC was performed with a $\mathrm{C}_{18}$ packed column $(250 \times 10 \mathrm{~nm})$ and using a DAD detector.

\subsection{Animal Material}

The soft coral Sinularia sp. was collected from the inner coral reef at a depth of around $8 \mathrm{~m}$ in Hainan Island of China, in May 2004, and the samples were frozen immediately after collection. The specimen was identified by Leen van Ofwegen (National Museum of National History Naturalis). The voucher specimens (HSF-15) are deposited at the State Key Laboratory of Natural and Biomimetic Drugs, Peking University, China.

\subsection{Extraction and Isolation}

The soft coral Sinularia sp. $(3.7 \mathrm{~kg})$ was homogenized, and then extracted with $95 \% \mathrm{EtOH}$ $(5 \mathrm{~L} \times 3)$. The EtOH extract $(102.5 \mathrm{~g})$ was partitioned between $\mathrm{H}_{2} \mathrm{O}(400 \mathrm{~mL})$ and EtOAc $(200 \mathrm{~mL})$. The EtOAc fraction $(10.0 \mathrm{~g})$ was subjected to column chromatography $(3.5 \times 25 \mathrm{~cm})$ using 160-200 mesh Si gel $(120 \mathrm{~g})$ and was eluted with a gradient of petroleum ether $(\mathrm{PE}) /$ acetone $(20: 1,10: 1,1: 1)$ to obtain nine fractions (F1-F9). F3 $(260 \mathrm{mg})$ was fractionated on an ODS column $\left(\mathrm{C}_{18}, 2.0 \times 25 \mathrm{~cm}\right)$ and eluted with a gradient of $\mathrm{MeOH} / \mathrm{H}_{2} \mathrm{O}(75 \%-100 \%)$ to collect three portions PA-PC. Portion PB $(85 \% \mathrm{MeOH}, 180 \mathrm{mg})$ were then subjected to a Sephadex LH-20 column $(1.5 \times 35 \mathrm{~cm})$ eluting with acetone to give $2(7.0 \mathrm{mg}), 3(11.7 \mathrm{mg})$, and $4(2.6 \mathrm{mg})$. Portion PA (75\% $\mathrm{MeOH}, 70 \mathrm{mg})$ was subjected to semi-preparative HPLC (ODS, $5 \mu \mathrm{m}, 2 \times 25 \mathrm{~cm}$ ) with $50 \% \mathrm{MeOH}$ as a mobile phase to obtain 5 (1.5 mg), 6 (1.4 mg), 7 (2.4 mg), and 10 (3.2 mg). Compounds 1 (14.9 mg), 8 (3.5 mg) and 9 (3.4 mg) were isolated from F4 (300 mg) using Sephadex LH-20 column $(1.5 \times 35 \mathrm{~cm})$ and semi-preparative RP-18 HPLC $(5 \mu \mathrm{m}, 2 \times 25 \mathrm{~cm})$ with $45 \% \mathrm{MeOH}$ as a mobile phase.

\subsection{Computational Calculation}

The computational ECD, specific rotation, and ${ }^{13} \mathrm{C}$ NMR calculations were performed by the B3LYP functional and a generic basis set, employ the $6-311+\mathrm{G}(d, p)$ basis set [21,22]. This generic basis set has been shown to be effective, both efficient and reliable, in predicting structural and reactivity properties for homogeneous systems. All calculations are performed with the Gaussian 03 package with tight self-consistent field convergence and ultrafine integration grids. 


\subsection{Larval Settlement Bioassays}

Adults of the barnacle Balanus amphitrite Darwin were exposed to air for more than $6 \mathrm{~h}$, and then were placed in a container filled with fresh $0.22 \mu \mathrm{m}$ filtered sea water (FSW) to release nauplii. The collected nauplii were reared to cyprid stage according to the method described by Thiyagarajan et al. [23]. When kept at $26-28{ }^{\circ} \mathrm{C}$ and fed with Chaetoceros gracilis, larvae developed to cyprids within four days. Fresh cyprids were used in the tests.

\subsection{Cytotoxic Assay}

The cytotoxic properties of the isolated compounds were tested in vitro using human tumor cell lines including human ovarian carcinoma cell line A2780, human lung adenocarcinoma epithelial cell line A549, human gastric carcinoma cell line BGC823, human hepatoma cell line Bel7402, and human colonic carcinoma cell line HCT-8 by MTT method.

Sinularone A (1): obtained as colorless oil; $[\alpha]_{\mathrm{D}}^{23}+7.26(c=0.27, \mathrm{MeOH})$; IR $(\mathrm{KBr}) v_{\max } \mathrm{cm}^{-1}$ : 2956, 2868, 1738, 1717, 1457, 1407, 1368, 1262, 1158, 1079; ${ }^{1} \mathrm{H}$ and ${ }^{13} \mathrm{C}$ NMR data, see Tables 1 and 2; HRESIMS (m/z): $259.1674[\mathrm{M}+\mathrm{Na}]^{+}$(calcd. for $\left.\mathrm{C}_{15} \mathrm{H}_{24} \mathrm{O}_{2} \mathrm{Na}, 259.1674\right)$; $\mathrm{CD} \lambda_{\max } \mathrm{nm}(\Delta \varepsilon): 212(-2.8)$.

Sinularone B (2): obtained as colorless oil; $[\alpha]_{\mathrm{D}}^{23}+0.60(c=0.43, \mathrm{MeOH})$; IR $(\mathrm{KBr}) v_{\max } \mathrm{cm}^{-1}$ : 3489, 2957, 2868, 1737, 1707, 1653, 1377, 1326, 1046; ${ }^{1} \mathrm{H}$ and ${ }^{13} \mathrm{C}$ NMR data, see Tables 1 and 2; HRESIMS (m/z): $305.1732[\mathrm{M}+\mathrm{Na}]^{+}$(calcd. for $\left.\mathrm{C}_{16} \mathrm{H}_{26} \mathrm{O}_{4} \mathrm{Na}, 305.1729\right)$; $\mathrm{CD} \lambda_{\max } \mathrm{nm}(\Delta \varepsilon)$ : $210(+3.6)$.

Sinularone C (3): obtained as colorless oil; $[\alpha]_{\mathrm{D}}^{23}+2.20(c=0.14, \mathrm{MeOH})$; IR $(\mathrm{KBr}) v_{\max } \mathrm{cm}^{-1}$ : 2954, 2920, 2863, 1730, 1710, 1654, 1458, 1377, 1164, 1062; ${ }^{1} \mathrm{H}$ and ${ }^{13} \mathrm{C}$ NMR data, see Tables 1 and 2; HRESIMS (m/z): $259.1315[\mathrm{M}+\mathrm{Na}]^{+}$(calcd. for $\left.\mathrm{C}_{16} \mathrm{H}_{26} \mathrm{O}_{4} \mathrm{Na}, 259.1310\right)$; $\mathrm{CD} \lambda_{\max } \mathrm{nm}(\Delta \varepsilon): 203(+5.0)$.

Sinularone D (4): obtained as colorless oil; $[\alpha]_{\mathrm{D}}^{23}-3.22(c=0.09, \mathrm{MeOH})$; IR $(\mathrm{KBr}) v_{\max } \mathrm{cm}^{-1}$ : 2958, 2926, 2872, 1778, 1710, 1657, 1458, 1378, 1165; ${ }^{1} \mathrm{H}$ and ${ }^{13} \mathrm{C}$ NMR data, see Tables 1 and 2; HRESIMS ( $m / z): 259.1313[\mathrm{M}+\mathrm{Na}]^{+}$(calcd. for $\left.\mathrm{C}_{16} \mathrm{H}_{26} \mathrm{O}_{4} \mathrm{Na}, 259.1310\right)$; $\mathrm{CD} \lambda_{\max } \mathrm{nm}(\Delta \varepsilon): 222(-1.3)$.

Sinularone E (5): obtained as colorless oil; $[\alpha]_{\mathrm{D}}^{23}+18.0(c=0.04, \mathrm{MeOH}) ; \mathrm{IR}(\mathrm{KBr}) v_{\max } \mathrm{cm}^{-1}$ : 3422, 2959, 2854, 1735, 1629, 1458, 1377, 1165; ${ }^{1} \mathrm{H}$ and ${ }^{13} \mathrm{C}$ NMR data, see Tables 1 and 2; HRESIMS $(m / z): 275.1612[\mathrm{M}+\mathrm{Na}]^{+}$(calcd. for $\left.\mathrm{C}_{15} \mathrm{H}_{24} \mathrm{O}_{3} \mathrm{Na}, 275.1623\right) ; \mathrm{CD} \lambda_{\max } \mathrm{nm}(\Delta \varepsilon): 221(+5.59)$.

Sinularone F (6): obtained as colorless oil; $[\alpha]_{\mathrm{D}}^{23}+22.6(c=0.03, \mathrm{MeOH}) ; \mathrm{IR}(\mathrm{KBr}) v_{\max } \mathrm{cm}^{-1}$ : 3420, 2958, 2856, 1730, 1612, 1459, 1377, 1120; ${ }^{1} \mathrm{H}$ and ${ }^{13} \mathrm{C}$ NMR data, see Tables 1 and 2; HRESIMS $(m / z): 275.1610[\mathrm{M}+\mathrm{Na}]^{+}$(calcd. for $\left.\mathrm{C}_{15} \mathrm{H}_{24} \mathrm{O}_{3} \mathrm{Na}, 275.1623\right)$; $\mathrm{CD} \lambda_{\max } \mathrm{nm}(\Delta \varepsilon): 219(-2.56)$.

Sinularone G (7): obtained as colorless oil; $[\alpha]_{\mathrm{D}}^{23}+4.03(c=0.10, \mathrm{MeOH})$; IR $(\mathrm{KBr}) v_{\max } \mathrm{cm}^{-1}$ : 3446, 2958, 2921, 1730, 1633, 1457, 1376, 1163; ${ }^{1} \mathrm{H}$ and ${ }^{13} \mathrm{C}$ NMR data, see Tables 1 and 2; HRESIMS $(m / z): 251.0886[\mathrm{M}+\mathrm{Na}]^{+}$(calcd. for $\left.\mathrm{C}_{11} \mathrm{H}_{16} \mathrm{O}_{5} \mathrm{Na}, 251.0895\right)$; $\mathrm{CD} \lambda_{\max } \mathrm{nm}(\Delta \varepsilon): 213(+1.21), 245(+0.31)$.

Sinularone H $(8)$ : obtained as colorless oil; $[\alpha]_{\mathrm{D}}^{23}+3.70(c=0.12, \mathrm{MeOH}) ; \mathrm{IR}(\mathrm{KBr}) v_{\max } \mathrm{cm}^{-1}$ : 3445, 2958, 2924, 1725, 1630, 1456, 1376, 1165; ${ }^{1} \mathrm{H}$ and ${ }^{13} \mathrm{C}$ NMR data, see Tables 1 and 2; HRESIMS $(m / z): 265.1041[\mathrm{M}+\mathrm{Na}]^{+}$(calcd. for $\left.\mathrm{C}_{12} \mathrm{H}_{18} \mathrm{O}_{5} \mathrm{Na}, 265.1052\right)$; $\mathrm{CD} \lambda_{\max } \mathrm{nm}(\Delta \varepsilon)$ : $213(+0.25), 230(-0.01)$. 
Sinularone I (9): obtained as colorless oil; $[\alpha]_{\mathrm{D}}^{23}+5.44\left(c\right.$ 0.18, MeOH); IR (KBr) $v_{\max } 3432,2959$, 2923, 1734, 1633, 1458, 1376, $1162 \mathrm{~cm}^{-1}:{ }^{1} \mathrm{H}$ NMR (600 MHz, DMSO- $\left.d_{6}\right) \delta: 1.67$ (1H, m, H-5a), $1.86(1 \mathrm{H}, \mathrm{m}, \mathrm{H}-5 \mathrm{~b}), 1.03$ (1H, m, H-6a), 1.12 (1H, m, H-6b), $1.22\left(14 \mathrm{H}, \mathrm{H}_{2}-7-\mathrm{H}_{2}-14\right), 1.50$ (2H, m, $\left.\mathrm{H}_{2}-15\right), 2.25\left(2 \mathrm{H}, \mathrm{t}, J=7.4 \mathrm{~Hz}, \mathrm{H}_{2}-16\right), 1.70\left(3 \mathrm{H}, \mathrm{s}, \mathrm{H}_{3}-18\right), 1.85\left(3 \mathrm{H}, \mathrm{s}, \mathrm{H}_{3}-19\right), 4.04(2 \mathrm{H}, \mathrm{q}, J=7.1 \mathrm{~Hz}$, $\left.\mathrm{Me}-\mathrm{CH}_{2}\right), 1.17(3 \mathrm{H}, \mathrm{t}, J=7.1 \mathrm{~Hz}) ;{ }^{13} \mathrm{C} \mathrm{NMR}\left(150 \mathrm{MHz}, \mathrm{DMSO}-d_{6}\right) \delta: 172.1(\mathrm{C}, \mathrm{C}-1), 123.9(\mathrm{C}, \mathrm{C}-2)$, 158.9 (C, C-3), 107.7 (C, C-4), $36.1\left(\mathrm{CH}_{2}, \mathrm{C}-5\right), 23.0\left(\mathrm{CH}_{2}, \mathrm{C}-6\right), 29.3\left(\mathrm{CH}_{2}, \mathrm{C}-7\right), 29.2\left(\mathrm{CH}_{2}, \mathrm{C}-8\right)$, $29.1\left(\mathrm{CH}_{2}, \mathrm{C}-9\right), 28.8\left(\mathrm{CH}_{2}, \mathrm{C}-10\right), 29.1\left(\mathrm{CH}_{2}, \mathrm{C}-11\right), 29.2\left(\mathrm{CH}_{2}, \mathrm{C}-12\right), 29.2\left(\mathrm{CH}_{2}, \mathrm{C}-13\right), 29.1\left(\mathrm{CH}_{2}\right.$, C-14), $24.9\left(\mathrm{CH}_{2}, \mathrm{C}-15\right), 33.9\left(\mathrm{CH}_{2}, \mathrm{C}-16\right), 173.2(\mathrm{C}, \mathrm{C}-17), 8.5\left(\mathrm{CH}_{3}, \mathrm{C}-18\right), 11.0\left(\mathrm{CH}_{3}, \mathrm{C}-19\right)$, $14.1\left(\mathrm{CH}_{3}\right), 60.0\left(\mathrm{CH}_{2}\right)$; HRESIMS $(\mathrm{m} / \mathrm{z}): 391.2456[\mathrm{M}+\mathrm{Na}]^{+}$(calcd. for $\mathrm{C}_{21} \mathrm{H}_{36} \mathrm{O}_{5} \mathrm{Na}, 391.2460$ ); $\mathrm{CD} \lambda_{\max } \mathrm{nm}(\Delta \varepsilon): 213(+1.25), 221(-0.02), 244(-1.10)$.

\section{Conclusions}

The Sinularia genus commonly produces cembranoids, which are considered to be the biomarkers for chemotaxonomy. The structural patterns such as cyclopentenone/cyclopentanone and unsaturated $\gamma$-lactone are unusual natural products found from the soft coral genus Sinularia. Present work provided a group of new cyclopentanone/cyclopanone and butenolide-type analogues to enrich the chemical diversity of Sinularia corals. The unprecedented 2,3-dimethylbutenolide based natural products were originally found from marine red algae [24] and brittle star [17], implying that dimethylbutenolides may be the signal molecules of the soft coral specimen to maintain coexistence with other benthos. This is the first report to indicate derivatives of unsaturated $\gamma$-lactone possessing potent antifouling activity. The metabolites containing a cyclopentenone or cyclopentanone ring are rarely discovered in marine soft corals, but they are often obtained from marine microorganisms. In addition, dimethylbutenolides showed potent antifouling activities, indicating that they contribute to a chemical ecological function. The literature survey revealed that the cyclopentenone group is relevant for cytotoxicity [25], thus cyclopentenone containing metabolites are regarded as the cytotoxins involved in chemical defense against predators. Whether the butenolides or cyclopentenones originated from a coral host or derived from other benthos serving as a food chain are uncertain.

The ethoxylated compounds such as 2, 7-9 are probably artifacts derived during the extraction process, whereas the naturally occurring forms are suggested to be free of the ethyl group.

\section{Acknowledgments}

This work was supported by grants from the NSFC (No. 30930109), National Key Innovation Project (2009ZX09501-014, 2009ZX09103-140, 201005022-4), and the International Cooperation Projects (2010DFA31610). We would like to thank Hua-Jie Zhu from Kunming Botanic Institute of CAS for the CD and optical rotation computation.

\section{References}

1. Lakshmi, V.; Kumar, R. Metabolites from Sinularia species. Nat. Prod. Res. 2009, 23, 801-850.

2. Anjaneyulu, A.S.R.; Sagar, K.S.; Venugopal, M.J.R.V. Terpenoid and steroid constituents of the Indian Ocean soft coral Sinularia marima. Tetrahedron 1995, 51, 10997-11010. 
3. Blunt, J.W.; Copp, B.R.; Munro, M.H.G.; Northcote, P.T.; Prinsep, M.R. Marine natural products. Nat. Prod. Rep. 2003, 20, 1-48.

4. Li, Y.; Pattenden, G. Novel macrocyclic and polycyclic norcembranoid diterpenes from Sinularia species of soft coral: Structural relationships and biosynthetic speculations. Nat. Prod. Rep. 2011, $28,429-440$.

5. Coll, J.C. The chemistry and chemical ecology of octocorals (Coelentrata, Anthozoa, Octocorallia). Chem. Rev. 1992, 92, 613-631.

6. Bhakuni, D.S.; Silva, M. Oceanography and marine biology, an annual review. Bot. Mar. 1974, $17,40-51$.

7. Dmitrenok, A.S.; Radhika, P.; Anjaneyulu, V.; Subrahmanyam, S.; Subba, R.P.V.; Dmitrenok, P.S. New lipids from the soft coral of Andaman islands. Russ. Chem. Bull. 2003, 52, 1868-1872.

8. Shindo, T.; Sato, A.; Horikoshi, H.; Kuwano, H. Two new polyhydroxy steroids from the Hainan soft coral. Experientia 1992, 48, 688-690.

9. Weinheimer, A.J.; Matson, A.J.; Hossain, M.B.; van der Helm, D. Marine anticancer agent: Sinularin and dihydrosinularin, new cembranolides from the soft coral Sinularia flexibilis. Tetrahedron Lett. 1977, 34, 2923-2926.

10. Schmitz, F.J.; Hollenbeak, K.H.; Prasad, R.S. Marine natural products: Cytotoxic spermidine derivatives from the soft coral Sinularia brongersmai. Tetrahedron Lett. 1979, 36, 3387-3390.

11. Searle, P.A.; Molinski, T.F. Phorboxazoles A and B: Potent cytostatic macrolides from marine sponge Phorbas sp. J. Am. Chem. Soc. 1995, 117, 8126-8131.

12. Kosuke, K.; Ikeda, T.; Muranaka, A.; Uchiyama, M.; Tominaga, M.; Azumaya, I. Synthesis and chiral discrimination of cyclic aromatic amides and the determination of their absolute configuration by TD-DFT calculation. Tetrahedron Asymmetry 2009, 20, 2646-2650.

13. Sundararaman, P.; Barth, G.; Djerassi, C. Optical rotatory dispersion studies. 134. Absolute configuration and circular dichroism spectrum of $(R)-\left[2-{ }^{2} \mathrm{H}_{1}\right]$ cyclopentanone. Demonstration of conformational isotope effect. J. Am. Chem. Soc. 1981, 103, 5004-5007.

14. Skowronek, P.; Gawronski, J. A simple circular dichroism method for the determination of the absolute configuration of allylic amines. Tetrahedron Lett. 2000, 41, 2975-2977.

15. Grimme, S.; Muck-Lichtenfeld, C. Calculation of conformational energies and optical rotation of the most simple chiral alkane. Chirality 2008, 20, 1009-1015.

16. Vila, J.A.; Baldoni, H.A.; Ripoll, D.R.; Scheraga, H.A. Unblocked statistical-coil tetrapeptides in aqueous solution: Quantum-chemical computation of the carbon-13 NMR chemical shifts. J. Biomol. NMR 2003, 26, 113-130.

17. Lee, J.; Wang, W.; Hong, J.; Lee, C.; Shin, S.; Im, K.S.; Jung, J. A new 2,3-dimethyl butenolide from the brittle star Ophiomastix mixta. Chem. Pharm. Bull. 2007, 55, 459-461.

18. Bhosale, S.H.; Nagle, V.L.; Jagtap, T.G. Antifouling potential of some marine organisms from India against species of Bacillus and Pseudomonas. Mar. Biotechnol. 2002, 4, 111-118.

19. Mizobuchi, S.; Kon-ya K.; Adachi, K.; Sakai, M.; Miki, W. Antifouling substances from a Palauan octocoral Sinularia sp. Fish. Sci. 1994, 60, 345-346.

20. Kwong, T.F.N.; Miao, L.; Li, X.; Qian, P.Y. Novel antifouling and antimicrobial compound from a marine-derived fungus Ampelomyces sp. Mar. Biotechnol. 2006, 8, 634-640. 
21. Teimouri, A.; Chermahini, A.N.; Emami, M. Synthesis, characterization, and DFT studies of a novel azo dye derived from racemic or optically active binaphthol. Tetrahedron 2008, 64, 11776-11782.

22. Picot, A.; Feuvrie, C.; Barsu, C.; Malvolti, F.; Guennic, B.L.; Bozec, H.L.; Andraud, C.; Toupet, L.; Maury, O. Synthesis, structure, optical properties, and TD-DFT studies of donor- $\pi$-conjugated dipicolinic acid/ester/amide ligande. Tetrahedron 2008, 64, 399-411.

23. Thiyagarajan, V.; Nair, K.V.K.; Subramoniam, T.; Venugopalan, V.P. Larval settlement behavior of the barnacle Balanus reticulates in the laboratory. J. Mar. Biol. Assoc. UK 2002, 82, 579-582.

24. Nomura, Y.; Kusumi, T.; Ishitsuka, M.; Kakisawa, H. 2,3-Dimethyl-4-methoxybutenolides from red algae Coeloseira pacifica and Ahnfeltia paradoxa. Chem. Lett. 1980, 9, 955-956.

25. Folmer, F.; Jaspars, M.; Dicato, M.; Diederich, M. Marine cytotoxins: Callers for the various dances of death. Gastroenterol. Hepatol. 2009, 2, 34-50.

Samples Availability: Available from the authors.

(C) 2012 by the authors; licensee MDPI, Basel, Switzerland. This article is an open access article distributed under the terms and conditions of the Creative Commons Attribution license (http://creativecommons.org/licenses/by/3.0/). 